\title{
A crise de 1929 e duas elites: São Paulo e Rio de Janeiro diante da Grande Depressão
}

\author{
Daniel de Pinho Barreiros*
}

Resumo: O artigo discute o impacto e as reações das elites nas cidades do Rio de Janeiro e de São Paulo diante do crash da Bolsa de Valores de Nova Iorque, em outubro de 1929. Conclui-se que, diante da crise econômica, a preservação dos hábitos sociais tradicionais da elite carioca, em contraste com os sintomas de desestruturação percebidos entre a elite paulista, se deve ao enraizamento urbano da primeira.

Abstract: The article discuss the impact and the reactions of the elites in the cities of Rio de Janeiro and São Paulo in the context of the crash of the New York Stock Exchange (october, 1929). Concluding, we state that the traditional social habits among the carioca elite are preserved due to their urban ties, in contrast with the symptoms of social disruption noticed in the behavior of the paulista elite.

Palavras-chave: Elites. Grande Depressão. Hábitos sociais.

Key words: Elites. Great Depression. Social habits.

Década de 1920. A elite brasileira desfrutava de momentos de nova esperança com o restabelecimento das atividades econômicas na Europa, o aumento do consumo e a elevação dos preços do café com o fim da Grande Guerra. Motivos não faltavam para que refinados senhores e distintas damas frequentassem os ambientes mais chics da Capital da República e vivessem seu sonho de Civilização, lotando o Jockey Club ou os salões de baile. Com a elite agroexportadora no poder, a política

* Professor Civil do Departamento de Ensino e Pesquisa - Exército Brasileiro. Pós-doutorando em História pelo PPGH-UFF. Doutor em História pela UFF. Pesquisador Associado do Laboratório "Idéias, Intelectuais e Instituições" (CNPq-UFF); e-mail: daniel@cmrj.ensino.eb.br

Estudos Ibero-Americanos, Porto Alegre, v. 35, n. 1, p. 128-144, jan./jun. 2009 
econômica se tornou instrumento de garantias para este setor. Esforços firmes para a valorização do produto, reduzindo sua oferta no mercado mundial e garantindo preços foram fonte de rentabilidade muito alta para os produtores e mais ainda para os financistas, promovendo incremento grandioso da produção. Tamanho era este crescimento que o acúmulo de estoques retidos para valorização era cada vez maior - e com o tempo, menos escoados.

Uma catástrofe se seguiu - o craque da Bolsa de Nova Iorque em outubro de 1929. Queda brusca de preços, fim do financiamento externo, o consumo desaba. O caos. E pensar que não muito antes a elite pensava navegar por águas plácidas. Dentro disso, poderemos verificar no estudo que segue o modo pelo qual esta mesma classe viveu e entendeu a crise, tendo como fonte periódicos da época.

Voltando os olhos, em primeiro lugar, para as elites cariocas da Belle Époque, o que as diferenciava daquela estreitamente vinculada ao Segundo Reinado e aos interesses cafeeiros, bem como da elite paulista? Como se constituía, e com que novas características se relacionava? Com que significado inédito nascia esta nova fração dominante? De que modo permaneceu incólume diante dos tempestuosos dias oriundos da crise do café e da Crise Internacional de 1929, sem sequer reorganizar seus padrões de manutenção? A chave de todo o entendimento reside na Civilização.

E para tal compreensão, faz-se necessária uma apreciação sobre a cidade e sua metamorfose, que varou as primeiras décadas do século seguinte. Por todo o século XIX, a cidade do Rio de Janeiro permaneceu condenada à sua própria sorte. Motivos rurais faziam parte da paisagem corrente deste centro, mesmo sendo considerado o mais populoso, e porque não dizer, cosmopolita. O ideal da "Civilização ao alcance dos trópicos" ainda não parecia ser algo disseminado. Era certo que a maioria dos brasileiros encontrava na Europa algo realmente distinto e superior, mas pareciam conformados com sua situação de "inferioridade", e "aceitava-se com naturalidade a precária adoção de tecnologias, costumes e capitais estrangeiros no Rio de Janeiro, reflexo das realidades neocoloniais" (Needell, 1993, p. 48).

A gestão de Campos Sales, iniciada em 1898, marcou o início de uma ruptura com a cidade colonial. Em nome do "Progresso" veio grande quantia de capitais ingleses, bem como uma proposta mais clara de incentivos à penetração européia e de seu padrão de desenvolvimento, expressa também no apoio à imigração. $O$ contexto gerado e as novas tendências modernizantes possibilitaram as audaciosas reformas urbanas, 
sob a liderança da dupla Rodrigues Alves/Pereira Passos (Benchimol, 1992).

O retrato do triunfo da cirurgia urbanística parecia ser a abertura da Avenida Central. Mais do que sua importância como via de tráfego, trazia em si um caráter de extremo simbolismo. Afinal, tratava-se de um verdadeiro bulevar dentro da cidade mais importante do país, constituído do que tinha de mais nobre e "civilizado" pelo mundo ocidental. Na imponência dos novos prédios e das fachadas, pretendiam os reformadores deixar estampado um recado para todo o mundo: o "Rio Civiliza-se!"

As reformas urbanas na cidade pareciam cada vez mais inadiáveis para a efetivação de um projeto de atração de maiores capitais, imigrantes e relações comerciais com a Europa. A capital argentina passara por reformas "civilizadoras" pouco tempo antes, e tinha sido muito bem sucedida com tal empresa (Gutman e Hardoy, 1992). Neste contexto, Pereira Passos é comissionado para ocupar a prefeitura da cidade e conduzir seus planos de mudança, tendo à frente o Brasil e em mente a França.

A importância da cidade do Rio de Janeiro como centro administrativo, comercial, financeiro e industrial sempre fora das maiores, e mesmo com seu setor cafeeiro ultrapassado pelo similar paulista, manteve-se fundamental pelas funções supracitadas. Neste princípio de século XX, sua importância como peça-chave da inserção internacional do Brasil era ainda mais fundamental, e isso foi percebido pelos altos círculos do poder republicano. Este novo papel já ficava patente nos últimos anos do século XIX, mesmo antes de Campos Sales ou Rodrigues Alves.

A transformação do Rio de Janeiro em uma verdadeira "vitrine do regime e das ligações mais eficientes de uma ressurgente economia neocolonial" (Needell, 1993, p. 54), o que implicava diretamente no seu afrancesamento, foi meta principal do governo do presidente Rodrigues Alves, fazendeiro paulista como seu antecessor, sendo um legítimo representante dos antigos interesses dominantes, bem como das novas tendências emergentes. Aliás, eram as fachadas monumentais que levavam os louros pela mudança efetivada, uma vez que se conseguiu, no Rio de Janeiro, combiná-las com edificações de caráter bastante modesto. Verificava-se que a aparência frontal dos edifícios tinha características muito modernas, estilo Beaux-Arts, e o restante da obra era simples e utilitário. Os prédios da Avenida Central traziam, por assim dizer, "um corpo brasileiro numa máscara francesa" (Needell, 1993, p. 66). 
Devemos lembrar que a dissimulação, a "arte de esconder", desde o século XIX, era um princípio muito caro às elites que se pretendiam "civilizadas", e estava determinada nos manuais de bons costumes. No Brasil, ela encontrou ampla aceitação por parte de uma sociedade escravocrata que pretendia abafar de todas as maneiras as consequências do seu sistema. Mostrou-se vital para um império recém-formado, que lutava por ocultar a falta de tradição das suas instituições. Para uma nobreza muitíssimo recente, urgia a necessidade de assimilar as "regras do bom-tom" para o convívio na Corte.

Desmorona o Império e surge uma República sob a égide do positivismo, com propostas de modernização e "Progresso", sublimadas de algum modo posteriormente pela ressurgência do poder dos latifundiários. E a busca por um assento à direita das "nações superiores" tomava ainda maior dimensão. Fala constante nas bocas mais ilustres da belle-époque tropical, estaria a necessidade de "civilização" às pressas, ilustrada devidamente pela arquitetura da Avenida Central, regida pelo mesmo princípio aristocrático da "arte de esconder"? Afinal, "não é a falsidade que nos faz dissimular nossos defeitos senão a vontade de escondê-los?" (Roquette, 1997, p. 28).

E todo este jogo de ocultar correspondia muito bem aos desígnios almejados pelas elites, criando de fato uma "fantasia de Civilização"; no entanto, a aparência moderna da Avenida Central não se limitava ao aspecto estético. Funcionando como verdadeiro mecanismo de conexão neocolonial, no bulevar acontecia o comércio de produtos finos provenientes do Velho Mundo, promovendo padrões de consumo próprios do ocidente europeu. No coração da cidade as elites urbanas pareciam realmente encontrar o elemento que poderia elevá-las ao estatuto máximo da civilidade.

A maior parte dos jornalistas foi porta-voz de toda a euforia das classes abastadas diante das reformas "civilizatórias". Atribuíram às mesmas a importância de permitir ao Brasil livrar-se dos mais ferrenhos obstáculos ao "Progresso" e à "Civilização". Documentaram com ênfase a destruição de uma ordem de coisas que deveria manter o país em moldes tradicionais. Viram e deleitaram-se com o ataque obstinado às condições insalubres da cidade, bem como sua ineficiência para as exigências de um mundo novo (Rocha, 1995). Assim falaram os jornais da cidade:

O fato demonstra o grande interesse da população pelo importante melhoramento que o atual Governo lega á Capital do país. Esse interesse, apressamo-nos em dizê-lo, é de todo justificado. O 
estrangeiro que visitar agora a nossa Capital já tem na Avenida [Central] um belo exemplo do progresso material que o Rio de Janeiro se sente resolvido a realizar. Está de vez morta a exclusividade de sedução que a naturaleza, e só ela, exercia sobre quantos estranhos nos visitavam. Subsistirá sempre a sedução das baías, das árvores e dos morros, mas a Avenida já prova que estamos resolvidos a construir outras jóias que nós mesmos fabriquemos sem nos limitarmos tão somente a exibir aquelas em que de modo algum trabalhamos. ${ }^{1}$

Sendo a grande mentora de uma verdadeira reviravolta no plano urbanístico e social, mudança esta conservadora e ao mesmo tempo anti-tradicionalista, cabe-nos agora perguntar, afinal, qual era a natureza tão específica desta fração dominante da sociedade do Rio de Janeiro neste começo de século? O modo pelo qual se comportou diante de uma torrente de adversidades socioeconômicas globais pode trazer-nos algumas luzes sobre a problemática.

A posição assumida pelo café na economia republicana chegou de fato em níveis de grandeza absoluta, assunto este que já foi exaustivamente estudado (Vilella e Suzigan, 1973; Furtado, 1954; Prado Jr., 1970). Além de sua posição de destaque, classificara-se logo após a virada do século como o principal produto primário a participar da rede de comércio internacional, sendo por excelência o artigo pelo qual o Brasil realizou sua participação na divisão internacional do trabalho. Inúmeros foram os fatores para a primazia do Brasil na produção do café, que vão da existência de terras propícias, imigração européia, etc., esta última representando elemento crucial para o surto produtivo no setor, dentro da questão conjuntural da Abolição da escravidão.

Aliás, fazia parte da política de modernização empreendida pela República o incentivo e amparo à imigração, com uma organização tal empreendida pelo Estado que englobava inclusive um sistema de propaganda no exterior. Sendo assim, a grande massa de estrangeiros, em maioria italianos, alojou-se em terras paulistas, direcionados para as lavouras de café, através de uma bem sucedida política de atração feita pelo agora descentralizado governo de São Paulo, fruto do tão almejado federalismo republicano.

Tendo uma evolução cíclica, com períodos de desenvolvimento e declínio de dadas áreas sucessivamente, o ápice estava sendo atingido no Oeste paulista; ficava confirmada a decadência da lavoura cafeeira

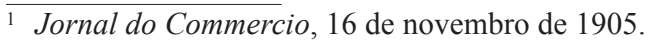


na maior parte das áreas, iniciada ainda sob o Império, como no Rio de Janeiro e em Minas Gerais.

Somente as ruínas de velhas mansões senhoriais, antigas residências de opulentos fazendeiros, denotam nelas a rápida passagem da riqueza do café; as plantações desapareceram e em seu lugar não encontramos outra coisa que uns pobres pastos que alimentam gado miserável e ralo (Prado Jr., 1970, p. 227).

Tais foram os avanços da cultura cafeeira, mesmo com técnicas agrícolas rudimentares, que sua grande expansão não tardou em trazer riquezas. Tão logo, porém, o café pecaria pelos seus excessos, e não pela falta. As nuvens negras da superprodução despontavam no horizonte, e encobririam os céus límpidos da República por toda a sua história, até os dias atuais.

A avalanche de crédito decorrente dos primeiros anos da República propiciara um aumento estrondoso da área cultivada e dos investimentos, que em 1896 já frutificava. Uma pequena torrente parecia próxima, mas nada preocupante. "Verificavam-se então os sintomas clássicos da superprodução: declínio dos preços, formação de estoques invedáveis" (Prado Jr., 1970, p. 228). Ainda no início, os preços em queda puderam ser "mascarados" pela desvalorização cambial. Estabilizada a moeda, porém, com a política austera e conservadora de Campos Sales, em 1898, os ventos sopram, dissipando a neblina, deixando à mostra a tempestade vindoura.

Tentou-se remediar a situação, sabendo que o excesso produtivo era a raiz do problema. A imposição de um tributo sobre as novas plantações não foi suficiente para evitar a saturação dos mercados para o produto. A situação manteve-se em certo equilíbrio até a década de 20, quando os sinais do dilúvio começaram a ficar mais claros. Depois do ano de 1925, o crescimento dos estoques foi cada vez mais recorrente e permanente, promovendo-se a eliminação sistemática de grande parte do produto, para manutenção de preços. Caio Prado Jr. nos lembra que

aparentemente a situação da lavoura era próspera: os altos preços do café prometiam larga margem de lucros. Prometiam, apenas, porque efetivamente não se vendia e exportava senão uma parte da produção. $\mathrm{O}$ resto permanecia retido à espera de oportunidade que nunca chegará. O pior é que depois de alguns anos de funcionamento do plano, não havia mais como sair da situação artificial e precária que se criara (Prado Jr., 1970, p. 235).

Os sinos não tocaram a tempo. Os habitantes daquela vila não conseguiram fugir para as colinas antecipadamente. Todas as medidas 
de controle econômico, os sacos de areia que protegiam a população contra a represa em frangalhos, não foram suficientes. E 1929 ficou marcado como o ano em que a inesperada tempestade desabou sobre as cabeças dos esperançosos, que viviam o ápice de suas potencialidades. Com a quebra da Bolsa de Nova Iorque, suspendeu-se o crédito externo e o financiamento da manutenção do café em estoque. Ao proceder à liquidação dos débitos, a catástrofe foi tamanha: os novos preços não eram suficientes para fornecer base de pagamento das dívidas. Falência geral.

Como se comportava a capital do café? A importância da cidade de São Paulo estava diretamente ligada ao mundo rural, de onde provinha sua elite. Por volta dos anos 1880 , já se podia observar claramente a ascendência de intermediários urbanos, constituídos em escritórios comerciais, fornecendo financiamento aos cafezais, mediando compra e venda do produto, bem como terras e lotes urbanos. A maior parte da função destes funcionários da urbe voltava-se para o produto agrário.

Podemos perceber a tamanha simbiose entre esta cidade e o mundo rural através dos avanços nos transportes. Podendo manter contato rápido com suas terras no interior, parte dos fazendeiros passou a viver na cidade e a desfrutar dos seus confortos e avanços. Richard Morse acrescenta mais sobre os proprietários rurais absenteístas:

Como moradores da cidade possuidores de riqueza, prestígio social e instrução de nível superior, muitos deles ingressaram em atividades econômicas urbanas - como diretores de estradas de ferro, pioneiros da indústria, banqueiros, etc. - ou em profissões com que estavam familiarizados desde os tempos de estudantes, tais como as lides forenses, a política ou jornalismo (Morse, 1970, p. 223).

Interessa perceber como os estratos burocráticos e profissões estritamente de caráter urbano eram exercidos por elementos vinculados ao universo rural. Eram a elite letrada da cidade, mostrada como aquela que detinha maiores possibilidades de fornecer educação avançada aos seus filhos. Possuíam status de maior grandeza pela sua posição socioeconômica rural, dentro de um ambiente urbano. Tratava-se de fato de uma elite dualizada, tendo sua base de acumulação e padrões de vida no campo.

Lembremos que no Rio de Janeiro, Pereira Passos também era filho de fazendeiros e foi por isso que igualmente pôde estudar no exterior. Porém, como será visto mais adiante, seus vínculos com o passado rural desfizeram-se a partir de sua geração, como foi regra para a maioria da elite letrada carioca. 
O representante mais característico, por vezes até caricato, desta aristocracia rural dualista em São Paulo era o "Coronel": chefe político medievalesco de áreas interioranas, que

no seu período áureo de 1890 a 1920 - manipulava as eleições locais, controlava a venda de terras, exercia pressão para determinar os percursos de estradas de ferro de modo a favorecer suas terras e retribuía como pai magnânimo a lealdade de seus eleitores. É difícil julgá-lo com severidade. Tal como o bandeirante que deixava outrora a civilização para desbravar e dominar o sertão agreste e desconhecido, o Coronel surgia dos opulentos cafezais para tornar-se o senhor pródigo e arrogante da metrópole caótica (Morse, 1970, p. 279).

Inúmeros são os exemplos das famílias que mantinham interesses duplicizados, podendo citar-se a família Prado, com membros reunindo as posições de bacharéis, cafeicultores, investidores urbanos, fundadores do Jóquei Clube Paulistano, políticos e industriais. Esta elite moldava e fazia funcionar uma cidade ainda provinciana e ruralizada, reformada modestamente durante o último quartel do séc. XIX, mas nada comparável à experiência do projeto carioca.

A ruína provocada pela tempestade em céu azul, a correnteza implacável das crises do café e a Crise Mundial de 1929, não poupou a existência deste grupo dominante. Aqueles que antes se beneficiaram e legitimaram através do spencerismo eram consumidos pelas suas leis (Graham, 1973, p. 248). A seleção natural aplicada às sociedades, com a qual se deleitaram nos seus momentos de glória, na adversidade, eliminava-os um por um. As lideranças foram progressivamente desaparecendo; os abalos posteriores a 1902 e principalmente a conjuntura formada na década de 1920 arrasaram toda a matriz de seu poder socioeconômico, transformando esta aristocracia rural-urbana em "farrapos de prestígio social" (Morse, 1970, p. 235).

Observava-se então a ascendência de novos líderes, agora com vinculações estritamente urbanas, em maioria estrangeiros, sem ligações e heranças em comum com a tradicional aristocracia paulista. A importância nacional da cidade de São Paulo afirmar-se-ia com sua nova elite mentora da industrialização, iniciada ainda no Império e confirmada principalmente no período posterior à Revolução de 1930 . Tendo a elite agroexportadora em prantos aos seus pés, carente do prestígio que perdera, a elite urbana poderia sarcasticamente voltar-se para ela e consolá-la com as seguintes palavras: 
A vida dos animais selvagens é uma luta pela existência. Devem utilizar ao máximo todas as suas capacidades e energias para salvar sua vida e defender sua prole durante a idade jovem. A possibilidade de encontrar o alimento durante as estações menos favoráveis e de fugir aos ataques dos inimigos mais perigosos, são as condições fundamentais que determinam a existência, seja do indivíduo seja da espécie (Darwin, 1992, p. 42).

Os jornais são muito felizes na tarefa de registrar um ambiente socio-histórico. O Correio da Manhã, periódico carioca, trazia todos os dias os devidos informes sobre a crise em curso, em âmbito nacional e internacional. O mês de outubro de 1929 é o mais intenso em matérias sobre o tema, evidentemente pelo mesmo ter sido palco da já falada quebra da New York Stock Exchange. A linguagem pela qual se expressam os jornalistas cariocas transparece um olhar externalizado em relação à situação paulista.

Em nenhum momento o jornal mostra-se despreocupado com a catástrofe econômica, muito embora o assunto não tenha conseguido ocupar mais páginas que as seções de política internacional, com matérias sobre o conflito sino-soviético, a doença e morte de von Büllow, sucessor do chanceler alemão Bismarck, ou nacional, com a sucessão presidencial. Teve menos regularidade ainda que a seção "Vida Social", esta sim campeã em assiduidade diária.

A Crise do Café não parece ter, em nenhum momento, influenciado sensivelmente o padrão de vida da classe dominante carioca. Verifica-se que no dia 18 de outubro a manchete "A Crise do Café - A safra e as condições pouco favoráveis dos mercados" convive harmoniosamente com o informe social, notificando a elite sobre a realização de "duas magníficas festas", a serem realizadas no Club Regatas Botafogo, a primeira delas no domingo dia 20, tratando-se de uma "reunião dançante", "emprestando assim um cunho de elegância à tarde desportiva", e a segunda no sábado 26, sendo "programa de festas artístico-sociais" sob a direção do senhor Luiz Gonzaga Botelho. ${ }^{2}$

A mesma edição traz ainda nota sobre a vindoura "Festa da Primavera", um convite do Grêmio Carioca de Letras e Artes, com conferência do poeta Luiz Carlos, membro da Academia Brasileira de Letras, que "falará sobre a Primavera". Um "Chá Dançante" a ser realizado no América Football Club, com a apresentação de uma Jazz Band promete "encantar as famílias americanas e sócios". O fim de

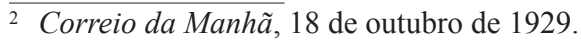


outubro promete alegrar as almas da elite com mais uma edição da "Hora da Arte", no Atlântico Club em Copacabana, paraninfada pela escritora Mercedes Dantas.

Ainda para o dia 26 do mesmo mês, o Club Atlético Acadêmicos de Medicina divulga uma "Soireé Dançante", sob patrocínio dos sócios e professores Abreu Fialho, Rocha Vaz e Abreu Monteiro, a ser realizada no já citado Club Regatas Botafogo. Em grande propaganda, o Theatro Cassino, a "Boite elegante do Rio", anuncia as famosas vedetes americanas "Dollie" e "Billie", "duas estrelas que são sóis", apresentando o seu "Broadway Show" e mais atrações, como uma Jazz Band, dez "girls" portenhas e mais. Não menos importante, a "Miss Irajá" senhorita Laura Nogueira anuncia "Chá Dançante" no "domingo próximo", no Club de São Christovam, em homenagem à Miss Brasil e com a presença de todas as "misses" cariocas. Para os boletins de apostas do Turf, com as cotações dos páreos dos grandes prêmios a serem disputados no Derby e Jockey Club, a crise econômica parecia distante, estando religiosamente divulgados na seção de "Sports" do Correio da Manhã.

No dia 20 de outubro, estava em destaque a seguinte manchete: “Em Londres, o 'Times' acha insuficiente o auxílio do Banco do Brasil". O jornal cobre a situação do preço do café em Nova Iorque, onde "durante toda a semana observou-se certo nervosismo devido às constantes flutuações deste artigo". ${ }^{3}$ Enquanto isso, a coluna social informava sobre mais uma recepção costumeira da Sra. Washington Luiz aos seus convidados, como era de costume às primeiras e terceiras segundas-feiras do mês.

É interessante como, mais adiante, Washington Luiz seria atacado agressivamente em uma nota não assinada, intitulada "Os que nada perdem", ${ }^{4}$ sendo acusado, junto com os "figurões da arrogante oligarquia paulista" de nunca terem sido "fazendeiros de café", e nada estarem perdendo com os efeitos da crise, da qual seriam cúmplices. Caso a acusação ao presidente tivesse alguma procedência, somada às recepções promovidas por sua esposa em meio a uma crise econômica, poderíamos sugerir que um importante cargo político na capital teria "urbanizado" o senhor Washington Luiz e sua família? Um cargo na burocracia estatal republicana carioca seria o suficiente para transformar a base material de acumulação de uma família? 
O dia 24 de outubro ficou marcado por duas tempestades, a primeira delas por força da "pior baixa na história da Bolsa de Nova York", e nesta mesma edição "o Departamento do Comércio anunciou que o terceiro trimestre de 1929 registrará o recorde de baixa em seis anos, do financiamento estrangeiro nos mercados americanos". ${ }^{5}$ A segunda foi regida pelas forças da natureza. Por ironia do destino, uma outra manchete anuncia uma "Violenta tempestade em Nova York", causando à população horas de infortúnios devido à torrencial chuva. Na edição do dia 26 de outubro, em função das baixas extraordinárias, foram posicionados "contingentes policiais na Wall Street a fim de impedir a possibilidade de perturbações da ordem". 6 Paralelamente, no mesmo dia 26 uma longa nota prestava contas ao público carioca dos males sofridos pela elite paulista:

$\mathrm{Na}$ impossibilidade de conseguirem mais rápido, mais enérgico, e tanto quanto possível radical [meio] para atenuar a crise econômica em que os prospectou a política do café, os lavradores paulistas cogitam de pôr em prática as medidas ao alcance de suas forças. Não podia ser mais premente a situação em que se encontram. Assoberbadas pelo custeio de duas safras, e não podendo fazer a produção chegar, regularmente, ao ponto de embarque para os mercados importadores, a lavoura não tem, sequer, por onde calcular com segurança, ou com aproximação relativa, até onde chegará a compensação aos consideráveis prejuízos, decorrentes da mora a que é compelida.

Achando-se em tão desagradável emergência, e na perspectiva de maiores constrangimentos financeiros, em conseqüência das quedas intermitentes e violentas nas cotações do café, os lavradores ... recorrem agora a um desdobramento de seus já muito pesados sacrifícios. ... O lavrador, é óbvio, desamparado, exausto, perdidas as esperanças na reparação imediata das tremendas avarias que ano por ano demonstram a incapacidade do aparelho destinado a estabilizar os preços do café, quer agora fazer últimas tentativas, ao alcance de suas possibilidades, visando suavizar os efeitos da insustentável situação. ${ }^{7}$

Certamente em climas mais amenos, o Club de São Christovam anuncia no dia 24 a abertura de seus salões para mais uma "soireé dançante, que a diretoria oferece aos seus associados e à elite, 
que o freqüenta", com direito à apresentação da Orquestra American Jazz. $^{8}$

A festa a ser promovida no dia 3 de novembro no Club dos Bandeirantes do Brasil, fechava o ano, e prometia, "por assim dizer, uma tarde elegante ... naquela sociedade freqüentada pelos mais finos elementos da nossa elite". 9 Junto com ela, era planejado um fantástico reveillon, comparecendo com anúncios no dia 31 e 30 de dezembro os principais clubs da elite carioca, com destaque para a programação do Jockey Club, com seu "Diner" dançante de gala, no Hipódromo.

Os melhoramentos urbanos no Rio de Janeiro avançavam, a maioria atendendo a pedidos de moradores, havendo inclusive reclamações através do periódico. O Cinema Central veiculava propaganda indicando sua reabertura. ${ }^{10} \mathrm{~A}$ Rua Senhor dos Passos prolongava-se depois de modesta demolição, passados muitos anos de pedidos dos negociantes e residentes. A nota ainda atribuía à administração da cidade descompromisso com o urbanismo (talvez por saudades de Pereira Passos...). ${ }^{11}$ Uma melhoria suburbana: a inauguração da circular do bonde de Inhaúma no ponto final. ${ }^{12} \mathrm{O}$ calçamento e a duplicação das linhas de bonde na Rua Clarimundo de Melo, na Piedade, causava alegria aos moradores e transeuntes. ${ }^{13}$

No dia 29 de outubro, divulgava-se: "O mercado esteve ontem numa situação de verdadeiro pânico. Em São Paulo pede-se a moratória e a emissão de papel moeda". Concomitantemente, a sucursal paulista do jornal editava nota no mesmo número, tratando da alarmante situação da capital paulista, cujo número de casas vazias ou abandonadas era alarmante. Deixava claro que a abundância não significava estar findado o problema da habitação, uma vez que as casas populares estavam cada vez mais raras e distantes do centro. As casas abandonadas eram em sua maioria palacetes e mansões, deixadas pelos seus ocupantes em busca de melhores condições nas cidades do interior, ou em busca de moradas menores. O jornal culpa a crise pelo fenômeno. ${ }^{14}$ Enfim, o contraste entre São Paulo e o Rio de Janeiro, e conseqüentemente entre suas camadas sociais privilegiadas, era evidente. O Rio de Janeiro

Correio da Manhã, 24 de outubro de 1929.

Correio da Manhã, 31 de outubro de 1929.

${ }^{10}$ Correio da Manhã, 25 de outubro de 1929.

1 Correio da Manhã, 18 de outubro de 1929.

2 Correio da Manhã, 27 de outubro de 1929.

13 Correio da Manhã, 31 de outubro de 1929.

${ }^{14}$ Correio da Manhã, 29 de outubro de 1929. 
é uma cidade que já nasceu “cidade". Nunca em sua história esteve subordinada aos interesses de uma aristocracia rural, embora tenha convivido com uma. Já nasceu com "alma urbana", lembrando João do Rio (Barreto, 1987). Seu cosmopolitismo expresso na condição de capital da colônia do Brasil, capital do Império e capital da República exigia mais do que uma cidade tributária a uma província ruralizada.

Quais os motivos objetivos que permitiram a elite carioca manter seus luxos e padrão de vida? Uma apreciação sobre as suas principais instituições formais poderá deixar este caráter bem mais claro. Façamos a distinção entre dois momentos: Segundo Reinado e Belle-Époque republicana, Rua do Ouvidor e Avenida Central. Durante a permanência do Império e de sua base de acumulação econômica agrária na Corte, de que estratos provinham os elementos que freqüentavam, por exemplo, o Cassino Fluminense? Via de regra eram "latifundiários enobrecidos, estadistas e grandes comerciantes", muitos deles ocupando posições de estabilidade na política imperial e em esmagadora maioria ligados a atividades vinculadas à exportação agrícola (Needell, 1993, p. 94).

$\mathrm{Na}$ fase final do Cassino, que correspondeu aos primeiros anos do século XX, qual era a composição social dos freqüentadores? Na quase totalidade, eram descendentes diretos daquelas famílias proprietárias rurais, mas que, depois de todas as mudanças econômicas decorrentes do fim do Império (Ferreira, 1994), da escravidão e do setor cafeeiro fluminense, "haviam se adaptado à nova era e se tornado bem-sucedidos elementos urbanos" (Needell, 1993, p. 94). Nas funções de diretoria, é aí que verificamos mais fortemente este caráter urbanizado da elite do Rio de Janeiro: eram negociantes, políticos, financistas, burocratas e profissionais liberais.

Ficava explicitado o maior grau de atividade urbana, negócios e profissões todas elas ligadas diretamente à cidade, e geralmente sendo nativas dali mesmo. Além do serviço público, a imprensa periódica e as letras também eram alternativas bem aceitas para os empregos urbanos, sendo opção ao trabalho burocrático (Dimas, 1993, p. 3). Eram raros neste local e tempo indivíduos que combinavam atividades no campo e na cidade, à moda dos Prado, em São Paulo, no mesmo período.

A Corte e as plantações de café haviam desapontado seus aristocratas, mas os setores comercial, industrial e burocrático urbanos passaram a oferecer alternativas lucrativas a eles, a seus descendentes e aos novos participantes (Needell, 1993, p. 95). 
A predominância do mundo urbano sobre o rural no Rio de Janeiro pode ser ainda melhor percebida segundo um mesmo corte analítico, mas desta vez tendo como objeto o Club dos Diários. O próprio nome já traz conceitos bem caros à nova realidade, remetendo aos "clubs", moda refinada franco-inglesa, e ao ato de viajar entre as estâncias de veraneio e os escritórios cariocas diariamente, ocupação difundida entre aqueles que poderiam dar-se a este luxo. O Club dos Diários, pelo seu nascimento mais recente (1895), trazia na composição de seus membros a marca ainda mais consolidada da influência dos profissionais urbanos. "Tanto em termos simbólicos quanto materiais, ocorreu uma substituição da antiga e ultrapassada base de riqueza e poder (o café fluminense) para outra mais vigorosa (as ocupações urbanas dos 'diários')" (Needell, 1993, p. 97).

Tanto o Cassino Fluminense quanto o Club dos Diários não resistiram à mudança progressiva de gostos na elite, vivenciada com maior força nos anos 20. A participação exigia uma preparação quase ritualística para as atividades (como as danças complexas e outras práticas cortesãs), exigindo do indivíduo uma postura ativa, herança certeira dos padrões do Segundo Reinado. Isso aos poucos entrava em choque tanto com uma tendência à passividade no lazer que tomava a frente, bem como com a falta de tradição de algumas famílias recém-chegadas ao mundo aristocrático. Tanto o Jockey Club quanto o Teatro Lírico atingiram maior longevidade justamente por proporcionarem às elites distinção social, com critérios de adesão altamente discriminatórios, além de oferecer encontro "civilizado" entre seus pares, e não exigir participação ativa.

As elites cariocas não viveram somente do que era novo. Em seu âmago foram preservados os mais rançosos frutos da cultura aristocrática, e foi esta permanência o alicerce de toda sua capacidade adaptativa em função da nova realidade socioeconômica que se instaurava. Seu esforço "conciliou mudanças generalizadas com a preservação de uma hierarquia social" (Needell, 1993, p. 41). No próprio Club dos Diários podemos encontrar exemplos. As mudanças no modus vivendi das elites não foram suficientes para abafar entre seus integrantes o valor social de residir em Petrópolis (sendo regra ter ofício no Rio de Janeiro, como já foi dito sobre os diários), permanecendo um local de elite, herança das épocas do Imperador. Sem falar do fato de que entre os seus componentes ainda constavam figuras fundamentais do Império, adaptadas ou não às novidades (Needell, 1993, p. 96-97).

A etiquette, elegância, a literatura, a arte, a boa oratória e indumentária, as posturas e os "bons modos" aristocráticos eram regra também 
entre as novas elites, mesmo desempenhando ela, em sua maioria, práticas burguesas. A matriz que fazia um Maciel Monteiro era a mesma que criava um Joaquim Nabuco (Needell, 1993, p. 136-142). ${ }^{15}$

Era esta a elite carioca, altamente adaptável, e com isso altamente aculturável. O paradigma anglo-francês era a moda, bem como assumir sem cautelas a aculturação. Exaltando a figura de Olavo Bilac (que foi editor de Kosmos), assim professa a imprensa seu auto de inferioridade:

Diante do esquife que encerra os despojos de Olavo Bilac, sob a tristeza que suscita a sua morte, avulta-se o apreço ao príncipe da poesia brasileira, por ele elevada e dignificada em surtos de aprimorado gênio artístico.

[...]. Precursor da Escola Parnasiana no Brasil, teve como Leconte de Lisle e Hereclia, o brilho, a cor, o ritmo, a suprema beleza, a intuição do maravilhoso tivesse nascido em França e escrito em francês e o seu nome seria universal. Mas, nascido no Brasil, expressando-se em português, idioma que ele cultuava com requintes não comuns, nem assim amesquinhou-se o seu prestígio. ${ }^{16}$

A sobrevivência à crise deveu-se à sua base urbana, afirmada com maior vigor após a decadência do café fluminense. A perda de poder perante as elites paulistas foi evidente, mas a classe dominante carioca foi mais além, encontrando ponto de apoio e uma referência para manutenção de seu status. Reformas modernizantes, contato com a cultura européia e ideais aristocráticos foram instrumentos de afirmação, propagando o neocolonialismo e forjando uma identidade pseudo-européia.

Em meio à fascinação pelo novo, o que realmente aclamaram foi a vitória inquestionável dos ideais europeizantes das elites, em detrimento do legado das massas, da herança afro-brasileira, dos costumes e das práticas estreitamente ligados à cultura da plebe. As reformas colocavam freios nas manifestações populares, como o Carnaval, e pretendiam findar com todos os elementos culturais circulantes que não representassem valores europeus. Ao dispararem em direção a uma pretensa "civilização" e modernidade, reafirmavam ainda mais seu caráter colonial, de assimilação e reprodução de valores impostos pelas potências hegemônicas (Needell, 1993, p. 70-73).

\footnotetext{
${ }_{15}$ Maciel Monteiro e Joaquim Nabuco se destacaram na alta sociedade do Segundo Império e da Belle-Époque carioca, respectivamente, pelas suas "qualidades" aristocráticas.

${ }^{16}$ A Rua, 28 de dezembro de 1918.
} 
Nos anos 20, através dos jornais, o termo "civilização" parece ter caído em desuso, e são raros os grandes empreendimentos progressistas serem tratados com este parâmetro. Falando dos manuais de bonscostumes, Lilia Schwarcz (Schwarcz, 1997, p. 31) afirma que com o passar do tempo, os hábitos mais básicos, como higiene, deixaram de ser explicitados nestes livros, diferentemente de um momento inicial, em que estes modos não estavam difundidos. O subentendimento de tais temas somente confirma seu enraizamento social. Desta maneira, a omissão do termo "civilização", pelo menos no que tange ao Brasil na Belle-Époque, parece a marca do sucesso deste projeto, do arraigamento da idéia. Com isso, estas elites encontraram seu lugar ao sol, mesmo tendo perdido toda a hegemonia de que dispunham durante o Segundo Reinado.

No mundo em mudança, no qual os membros, ou candidatos a membros, da elite buscavam conservar ou ganhar posições, estes valores estavam entre as poucas coisas que indicavam a continuidade e legitimação decorrentes da tradição e da identificação com o poder (Needell, 1993, p. 142).

Eis o triunfo da ilusão!

\section{Referências}

BENCHIMOL, Jaime Larry. Pereira Passos: um Haussmann tropical. A renovação urbana da cidade do Rio de Janeiro no início do século XX. Rio de Janeiro: Secretaria Municipal de Cultura, 1992.

DARWIN, Charles. A origem das espécies: esboço de 1842. Rio de Janeiro: Newton-Compton, 1992.

DIMAS, Antonio. Tempos Eufóricos (Análise da Revista Kosmos: 1904-1909). São Paulo: Ática, 1993.

FERREIRA, Marieta de Moraes. Em busca da Idade de Ouro. As elites políticas fluminenses na Primeira República. Rio de Janeiro: UFRJ/Tempo Brasileiro, 1994.

FURTADO, Celso. Formação econômica do Brasil. Rio de Janeiro: Fundo de Cultura, 1954.

GUTMAN, Margarita; e HARDOY, Jorge Enrique. Buenos Aires: Historia urbana del area metropolitana. Madrid: MAPFRE, 1992.

GRAHAM, Richard. Grã-Bretanha e o início da modernização no Brasil (1850-1914). São Paulo: Brasiliense, 1973.

MORSE, Richard M. Formação histórica de São Paulo. São Paulo: DIFEL, 1970. 
NEEDELL, Jeffrey D. A belle époque tropical: Sociedade e Cultura de elite no Rio de Janeiro na virada do século. São Paulo: Companhia das Letras, 1993. PRADO Jr., Caio. História econômica do Brasil. 13. ed. São Paulo: Brasiliense, 1970.

BARRETO, João Paulo (João do Rio). A alma encantadora das ruas. Rio de Janeiro: Secretaria Municipal de Cultura, 1987.

ROQUETTE, J. I. O código do bom-tom ou regras da civilidade e de bem viver no século XIX. São Paulo: Companhia das Letras, 1997.

ROCHA, Oswaldo Porto. A era das demolições. 2. ed. Rio de Janeiro: Secretaria Municipal de Cultura, 1995.

SCHWARCZ, Lilia Moritz. Introdução. In: ROQUETTE, J. I. O código do bom-tom ou regras da civilidade e de bem viver no século XIX. São Paulo: Companhia das Letras, 1997.

VILELLA, Annibal V.; SUZIGAN, Wilson. Política do governo e crescimento da economia brasileira (1889-1945). Rio de Janeiro: IPEA/INPES, 1973. 